\title{
Exploration on the Undergraduate Talent Training Mode on the Horizon of the Emerging Engineering Education: Take the Civil Engineering as Example
}

\author{
Wenbin Sun* \\ Faculty of Architecture and Civil Engineering, Huaiyin Institute of Technology, Huaian Jiangsu 223001, China \\ ${ }^{*}$ Corresponding author. Email: sunwb1969@hyit.edu.cn
}

\begin{abstract}
At present, a new round of social change and industrial revolution is unfolding rapidly, and new technologies and new types of industry and business emerge in an endless stream. The development of new industries requires a large number of interdisciplinary and outstanding engineering and technical talents. The construction of emerging engineering education arises at the historic moment under such historical background. The emerging engineering education lies in the understanding and response to the new types of industries and business in the future, and also lies in the new revolution of the traditional engineering education concept, curriculum structure and education system. In order to cope with these complex changes of engineering forms, the emerging engineering education must be redesigned from three aspects including but not limited to the return of engineering paradigm, the innovation of curriculum structure and engineering education system. The specific implementation path of emerging engineering education should pay attention on the new types of industry and business, the reconstruction of new courses, and strengthen policy adjustment and promote cooperation between administrative departments, industries, universities and colleges, and social institutions.
\end{abstract}

Keywords: Engineering education, Undergraduate talent training mode, Emerging engineering education, New types of industry and business.

\section{INTRODUCTION}

At present, higher education in China is facing the challenges of social change and industrial revolution. The new characteristics of informationization and Internet society, the sustainable development of society and environment, the change of knowledge formation and information dissemination. These changes and challenges of demands for talents in the future all have a profound impact on the direction of traditional engineering education mode [1].

In the new era, students who live in the age of the Internet can quickly access information from multiple channels and become more independent and intelligent. With the development of mass online open courses (MOOCs), young people's personal learning styles are changing and becoming more flexible, fragmented, networked, multidimensional and practical. To the young generation, needs of personal career development and success factors are also changing. They need to develop in an all-round way in ideal and value, insight and knowledge, practice and ability, culture and quality, etc. Only in this way can they have sustainable competitiveness to adapt to the development of the future society and challenges from social change and industrial revolution.

In order to meet students' demands of knowledge, ability and talent, undergraduate education not only undertakes the task of teaching courses and solving problems, but also sets up a platform, creates opportunities and provides life-education for students, so as to cultivate innovative talents with sustainable competitiveness. Therefore, students should be trained to have a sense of responsibility and mission for future global affairs and national development, to understand the changes in the process of social information, the promoting role of science and engineering technology in the change of social information and the impact on globalization, and to recognize these changes should have the knowledge, elements quality and competence. It is the new mission for universities and colleges in the 
construction of emerging engineering education to train innovative talents with sustainable competitiveness [24].

\section{TALENT TRAINING OBJECTIVES OF EMERGING ENGINEERING EDUCATION}

A scholar considers that the talent training mode is the talent training objectives and specifications as well as the methods or means to achieve these training objectives and specifications. The talent training objectives of the construction of emerging engineering education should be determined according to the talent demands of new technology, new industry and new business in the future.

China Engineering Education Accreditation Association (CEEAA), which is committed to improving the quality of engineering education in China through the development of engineering education certification, has established an international substantially equivalent engineering education certification system to serve the reform and development of engineering education, to help engineering education meet the needs of the government, industry and society, and to enhance the international competitiveness of Chinese engineering education.

From the exploration and practice of CEEAA, the talent training objectives of emerging engineering education should cultivate innovative talents with sustainable competitiveness. These innovative talents should have professional ability and comprehensive ability. Professional abilities include the abilities of theoretical analysis and abstract, problem understanding and solving, analysis and design, practice and application, development and management, continuous learning and improvement, etc. Comprehensive ability refers to the abilities of intercultural communication, project organization and team cooperation, innovation consciousness, and international competition ability [5].

Civil engineering accompanies human civilization and progress, is the oldest engineering technology. In universities and colleges, civil engineering is one of the oldest engineering majors. The talent training objectives of civil engineering can be divided into three types of technical, expanding and leading according to the different emphases of knowledge and technical ability and comprehensive ability. Talents of technical type are those with solid professional knowledge, skills and abilities in civil engineering, they are suitable for technical jobs. Talents of expanding type are those who have broad knowledge and abilities in addition to a certain professional knowledge, including knowledge of engineering organization, and economic and business operation, as well as the ability of cross-cultural communication, organization, management and teamwork. This type of talent is very popular with companies. Talents of leading type are those who master the relevant knowledge and ability of civil engineering field or industry on the basis of the expanding talents, and have broad insight and leadership. This type of talent is more likely to succeed.

The civil engineering discipline involves building construction, underground space development (including mine engineering), road engineering, tunnel engineering, bridge engineering, hydropower station, port engineering, offshore structures, water supply and drainage, infrastructure, and other industries. Civil engineers engage in planning, design, construction, management, research work, and other different jobs. The talents training of emerging engineering education in civil engineering should have different targeting, it can be developed diversified talent training objectives to meet the needs of society from the requirements of professional ability and expanding ability.

\section{TALENT TRAINING MODES OF EMERGING ENGINEERING EDUCATION}

The key to the construction of emerging engineering education is the reform and innovation of talent training mode. The talent training mode is a comprehensive concept on the approach, method, norm, process, means and correlation in the implementation of education [6-7].

Taking the transformation and upgrading of the traditional civil engineering as an example, the construction of emerging engineering education may relate to several training modes which can be considered many types, such as the research-based mode, inquirybased mode, comprehensive education mode oriented to the cultivation of comprehensive ability, industry application and practice mode based on excellent engineer training plan, project leader model by engineering training plan and project learning plan, innovative education mode of multidisciplinary and double-degree education based on Interne plus and multidisciplinary integration, information education model based on MOOCs/SPOCs and flipped classroom, international joint talent training mode.

In order to reconstruct a new high quality engineering talent training system, universities and colleges should update the educational concept and form the educational concept oriented to the development and sustainable competitiveness of students, demands of industry and business, requirements of society and government. The innovation of professional knowledge system should be carried out to construct a new professional knowledge of engineering which can adapt to the new industries, new business, and new technical. In order to implement the first-class education, universities and colleges should build many first-class teachers with multidisciplinary comprehensive innovation capability. According to the new laws of 
engineering development, universities and colleges should reform and innovate the talent training mode. They should build an interdisciplinary learning and discussion environment and create a multidimensional learning space for students and teachers. At the same time, innovation and entrepreneurship education system and platform should be built, which is an important feature of emerging engineering education. It is an important aspect of emerging engineering education to establish an ecological environment for collaborative education through universities-enterprise cooperation. In addition, it is necessary to establish a multi-level talent training quality evaluation system for the country, the industry and the universities and colleges that is suitable for the new industries and business.

To the civil engineering, it is one of the oldest traditional discipline. In order to reconstruct the curriculum system, universities and colleges should solve several following problems. Firstly, integrate the existing curriculum system and pay attention to the overall connection between courses. Secondly, adjust the proportion of class hours of each subject. The assignment of class hours should not only meet the rigor of the discipline, but also meet the requirements of professional certification standards. Thirdly, strengthen the construction of characteristic majors, high-quality courses and planning textbooks. Lastly, combine the actual situation of civil engineering major, strengthen the practice teaching. The experiment teaching implements the open management, tutors guide the student to carry on the independent innovation experiment, trains the students' innovation consciousness, enhances the students' ability to find the problems, analyze problems and the solve problems.

\section{KNOWLEDGE SYSTEM RECONSTRUCTION OF EMERGING ENGINEERING EDUCATION}

Emerging engineering education will produce a batch of new majors, and also transform and upgrade some traditional engineering majors to reflect the needs of interdisciplinary and cross-border integration as well as the development of new technology and new industry, so as to adapt to the new business, economy and industrial development. It can be expected that some of these new majors are derived and expanded from existing majors, some are organic integration of multiple majors, and some are crossover integration with the application industry.

The emergence of new majors, on the one hand, can adapt to the rapid changes of technology and economy, on the other hand, meet the challenge by the knowledge system reconstruction. According to the talent training objectives of both of professional ability and comprehensive ability, the talent training programs of new engineering majors should be scientifically and rationally formulated to support the achievement of the elements of talent training such as knowledge, ability and quality [8]. The professional curriculum system should also be designed according to this knowledge system, and universities and colleges can adjust it according to the orientation of running universities and colleges and the needs of employing people, giving consideration to the scientific nature, advanced nature and rationality.

With the development and progress of science and technology in civil engineering, prefabricated building, building information modeling (BIM), virtual reality (VR), structure health monitor (SHM) and many other new techniques are constantly applied in civil engineering, the talent training of traditional civil engineering is also facing transformation and upgrading. The talent training program of traditional civil engineering must reconstruct the knowledge system and curriculum system, and must increase the courses related to prefabricated building, BIM, VR and SHM to meet the needs of student development and industry.

\section{QUALITY ASSESSMENT ON THE CONSTRUCTION OF EMERGING ENGINEERING EDUCATION}

The quality assessment on the construction of emerging engineering education is a very important, and is also a very complicated problem. It is necessary to introduce a multidimensional and comprehensive evaluation system for the quality of engineering education. At present, the typical quality evaluation methods include engineering education accreditation, unified level examination, student and peer evaluation, social comprehensive evaluation, etc.

A unified professional ability testing platform, which is built jointly by educational institutions, industrial associations, social institutions, and administrative departments, can be employed to conduct a unified level examination to evaluate the professional level and ability of students trained by universities and colleges. In order to promote the construction of emerging engineering education in an orderly way, it is suggested that the national education administrative departments should establish a comprehensive social evaluation system based on the evaluation of industries and employers with high credibility, as well as the thirdparty evaluation and engineering education accreditation, so as to objectively evaluate and compare the quality and level of emerging engineering education in universities and colleges.

\section{CONCLUSION}

The construction of emerging engineering education needs long-term exploration and continuous practice, it is also a dynamic development process. Fudan 
Consensus [3], Tianda Action [9], Beijing Guide [10] constitutes a trilogy of the construction of emerging engineering and plays the main melody of talent training mode reform.

Facing transformation and upgrading, traditional engineering majors must take the initiative to strengthen the responsibility of serving national strategy and regional development, and constantly improve the talent training system and innovate the talent training mode based on the fundamental requirement of cultivating talents.

To the quality assessment of the construction of emerging engineering education, a multidimensional and comprehensive evaluation system for engineering education quality should be set up. The education quality assessment standards at the national, industrial and universities should be established to guide specialty construction and quality assurance.

\section{AUTHORS' CONTRIBUTIONS}

Sun Wenbin contributed significantly to collect literature and documents, make research planing, and write this manuscript.

\section{ACKNOWLEDGMENTS}

This research was financially supported by the Higher Education Research Fund of Huaiyin Institute of Technology (grant No. 2018XGJ16). It is also supported by the Higher Education Research and Teaching Reform Project from the Educational Department of Jiangsu Province (No. 2019JSJG307) and the Philosophy and Social Science Research Project from the Educational Department of Jiangsu Province (No. 2019SJA1662).

\section{REFERENCES}

[1] Ye Min, Qian Hui. The Originally in New Types of Industry and Emerging Engineering Education. Higher Engineering Education Research, 165(2017) 6-9. (In Chinese)
[2] Hu Bo, Feng Hui, Han Weili, et. al. Accelerate the Construction of New Engineering Projects and Promote the Reform and Innovation of Engineering Education. Fudan Education Forum, 15(2017) 2027. (In Chinese)

[3] Fudan Consensuses on the Construction of Emerging Engineering Education. Fudan Education Forum. 15(2017) 27-28. (In Chinese)

[4] Zhong Denghua. Connotation and Actions for Establishing the Emerging Engineering Education. Higher Engineering Education Research, 164(2017) 7-12. (In Chinese)

[5] Wu Tao, Liu Nan, Sun Kai. On the Key Abilities of Engineering Talents from Perspective of New Engineering Department. Heilongjiang Higher Education Research, 287(2018) 156-160. (In Chinese)

[6] Xia Jianguo, Zhao Jun. On the Reform and Development of Engineering Education in Local Universities and Colleges Based on Establishing Emerging Engineering Education. Higher Engineering Education Research, 164(2017) 15-19. (In Chinese)

[7] Gu Peihua. The Concept, Formwork and Implement Approaches of Emerging Engineering Education (3E) and the New Paradigm. Higher Engineering Education Research, 167(2017) 1-13. (In Chinese)

[8] Zhu Weihong, Peng Yunfei. Research on the Construction of Industrial College in Local Undergraduate Colleges and Universities under the Background of Emerging Engineering Education. Journal of Higher Education Management, 12(2018) 30-37. (In Chinese)

[9] http://www.moe.edu.cn/s78/A08/moe_745/201704/ t20170412_302427.html

[10] http://education.news.cn/201706/13/c_129631611.htm 